\title{
THE FORM OF CELESTINA: DRAMATIC ANTECEDENTS
}

\author{
Keith Whinnom $t$ \\ (edited by Alan Deyermond \\ Queen Mary \& Westfield College-London)
}

[From some time in the first half of 1966 to the late summer of 1969, the greater part of Keith Whinnom's research and writing was dedicated to a book on Celestina. This was originally planned as a fairly short guide for students, to be published by Tamesis: a longer book than the 158-page Lacarra 1990, and different in content (he described it in a letter of July 14,1966 , to D.W. McPheeters, as "a sort of critical commentary on the available criticism and theorizing"), but still accessible financially and intellectually to undergraduates. The origin of the book is to be found in the lectures that Whinnom gave at Trinity College, Dublin, where he was a faculty member from 1956 to 1961 ; these were extensively revised as lectures to graduate students at Emory University in the spring semester of 1965, and the text of those lectures provided the outline and some of the material for the book. As the book progressed, it became much more detailed, and by 1968 it seemed to me, as the Tamesis editor responsible for the project, that this was going to be not a students' guide but a guide for Celestina scholars, though Whinnom still saw his principal audience as the more advanced undergraduates. I think that soon after that he 
may have become daunted by the magnitude of the task, and it is fairly clear that, having suspended work on the book in August 1969 in order to prepare his Diego de San Pedro editions for Clásicos Castalia, he never returned to it.

I have given a detailed account of the book's history and contents elsewhere (Deyermond in press), and all that it is now necessary to add to the summary in the previous paragraph is that at the time when Whinnom interrupted his work on the book he had completed Part I (this is self-contained, and arrangements have been made to publish it as an independent book, The Textual History of "Celestina"), and the first two chapters of Part II, on antecedents and sources, were written in draft (a typescript with some deletions and substantial changes and interpolations). The first of these two chapters consists of a complex and very interesting discussion of problems of identifying Celestina's sources (I intend to publish this elsewhere), and the second constitutes the article printed below. I have - in addition, of course, to the normal procedure in editing from a penultimate draft - followed the same practice as in the two previous Whinnom articles that I have edited for Celestinesca. The work's title is given in the form that Whinnom later chose; this and other points of detail are silently emended, and bibliographical references expanded (Whinnom used the author-date system, but had not prepared the bibliography for the book at the time that he interrupted his work on it). References to the text of Celestina are to Cejador 1913, the only edition that it was realistically possible to cite when Whinnom was working on this project (he suspended work on it just as Severin 1969 was published). To substitute references to a more recent and better edition would not, I think, be useful except in a context of extensive reworking of this article so as to bring it up to date in the light of the last twenty-five years' research, and if that were done the article would no longer be Whinnom's. Similarly, the addition of recent bibliographical references has been kept to a minimum; any such additions are in brackets.

Had Keith Whinnom lived longer, he would certainly have wanted to contribute an article to Celestinesca's tribute to Peter Russell, a teacher for whom he felt both admiration and gratitude. I should have liked to contribute an article, but having recently written two long Celestina papers for the Proceedings of conferences I have nothing new to say that might deserve Peter Russell's attention. It is a privilege to be able to play a small part in this tribute by editing Keith Whinnom's article. ALAN DEYERMOND] 
a privilege to be able to play a small part in this tribute by editing Keith Whinnom's article. ALAN DEYERMOND]

The form of Celestina has long caused difficulties, the critics debating heatedly whether it is a play or a novel or something else again (there is a splendid anthology of all the nonsensical labels in Lida de Malkiel 1962: 64-66, n. 29). Ferdinand Wolf thought it was "epic-dramatic" ("Seine Forme ist in der That eine episch-dramatische", 1859: 280). Marcelino Menéndez Pelayo called it "un poema dramático" (1962: 220) but felt obliged to deal with it in a history of the novel, and, of course, innumerable writers have referred to it as a novel. As late as 1962, Stephen Gilman was insisting that Celestina is essentially a dialogue or a "dialogue novel," and wrote: "The outward sign of the inner uniqueness and originality of the Celestina was its twenty-one acts of unbroken dialogue. A book looking like this had never been printed or seen before; [...] before the Celestina there had been no systematic use of dialogue for its own sake, nothing resembling the two major dialogue forms today so taken for granted, the drama and the novel. [...] The Celestina in one stroke changed all this" (1962: 285-86). In all this two distinct problems are, I think, confused. The first of these is a pseudo-philosophical problem which might be rephrased: "When is a play not a play?" If a work is written, as Celestina is, in the way one would write a play, does it become "not a play" (a) if its author did not envisage it being performed by actors on a stage; (b) if, because of its length, scabrous episodes, or other considerations, it is unactable (Lida de Malkiel argues strenuously that it is not in fact unactable at all, 1962: 65-68); or (c) if it is, by some other less demonstrable criterion, "undramatic" (Gilman 1962: 301)? The question is merely frivolous in so far as it presupposes that all fiction is assignable to one or other of two clearly defined categories, novel or drama. Much more serious is the second problem, that of the "generic uniqueness" (Gilman 1962: 301) of the work. Celestina may be the first of its kind in Spanish, but it is by no manner of means unique; and if the first of the problems I have identified has any philosophical validity whatsoever, it must be discussed with reference to the entire genre of humanistic comedy. The critics have tended consistently to make Celestina even more of a miracle than it is, and have credited Rojas (or the author of Act I) with a capacity for innovation which would have been astounding in the twentieth century and impossible in the fifteenth. 
or which work Rojas and his predecessor borrowed their form, but we must identify a group of authors or works with which they could reasonably be presumed to have been acquainted. We must, that is, face the problem of transmission.

\section{Classical comedy: Plautus and Terence.}

Statements are repeatedly made in works of criticism and histories of literature that Celestina owes much to the Roman stage, and even that it is, specifically, a "Terentian comedy." 1 Rojas himself, indeed, in the first version of the acrostic verses, compared the old author's Act I with a play by Terence ("Jamás no vi sino terenciana" etc.), but he thought better of this and deleted the references to Terence from the revised verses of 1502 (perhaps by then he had actually read a play by Terence).

Plautus we really do not need to spend much time over. Menéndez Pelayo takes it for granted that Rojas was acquainted with Plautus (1962: 287-95), but Castro Guisasola could find not a single clear case of borrowing, and concluded that Plautus's "relaciones con La Celestina, séame lícito decirlo, se han exagerado" (1924: 50). The elements in Celestina which have been considered to be Plautine are:

a. The acrostic verses.

b. Certain stock characters, such as Centurio, regarded as an imitation of Pyrgopolynices, Plautus's Miles gloriosus, or one of his other braggart soldiers like Therapontigonus in Curculio; and Celestina, regarded as a development of the Plautine gobetween who appears in such plays as Asinaria, Cistellaria, Curculio, and Mostellaria.

c. The name of the character Sosia (a servant in Amphitruo).

d. The title Tragicomedia.

e. A number of commonplace ideas which appear both in the plays of Plautus and in Celestina.

The first three categories of similarities we can at once refer from Plautus to Terence, since the acrostic verses, the same stock characters, and the names not only of Sosia (who appears in Hecyra and Andria) but of various other Celestina personages are also to be found in Terence.

The term tragicomedia is a little bit more complex. ${ }^{2}$ There is, of course, no such genre in the classical theatre, and in the prologue 
to Amphitruo Plautus calls his play a "tragico-comoedia". as a joke. The term is, apparently, used only once between Plautus and Rojas, by Carlos Verardo, a Spaniard, in the dedication of a Latin work by his nephew Marcelino, Fernandus salvatus, of 1493. While insisting on Rojas's debt to Plautus, Menéndez Pelayo thought that it was "fuera de duda que Rojas conocía la obra de Verardo" (1962: 291). Castro Guisasola (1924: 52) was more inclined to see the influence of Verardo alone. I am unable to understand why it is impossible that the term tragicomedia (which is in any case not the "tragico-comoedia" of Plautus or Verardo) could not have occurred independently to Rojas.

Castro Guisasola lists a series of vaguely similar "verbal reminiscences" (1924: 53-56), but the closest parallels are: "Et ego et tua mater ambae / meretrices fuimus" (Cistellaria, I.1) with "tan puta vieja era tu madre como yo" (Cejador 1913: I, 98), and "Vides quae sim et quae fui ante?" (Mostellaria, I.3) with " $i$ Ay, quién me vido y quién me ve agora!" (II, 43), and they fail to convince Castro Guisasola. $^{3}$

Nevertheless, Castro Guisasola, following Menéndez Pelayo, insists on the dependence of Celestina on the Roman stage, and decides that Rojas relies heavily on Terence. The proofs he offers may be categorized as follows:

a. The acrostic verses.

b. The stock characters.

c. The names of certain characters: Parmeno appears in Eunuchus, Adelphoi, and Hecyra; Sosia(s) in Hecyra and Andria; Crito in Andria, Heauton Timorumenos, and Phormio; Thraso in Eunuchus; and Chremes - Alisa says in Act IV that she is going to visit the wife of Cremes - in Andria, Eunuchus, Heauton Timorumenos, and Phormio.

d. $\quad$ A number of "verbal reminiscences."

e. The dramatic technique. "Lo que principalmente ha asimilado Rojas del dramaturgo latino [es] la concepción dramática y técnica escénica, el arte de las situaciones, la infinidad y variedad de recursos artísticos para animar la escena, la expresión de los afectos; en suma, ese aliento vital" (1924: 86).

The acrostic verses are a particularly weak demonstration of dependence, since acrostic verse is cultivated throughout the Latin 
Middle Ages, and by numerous fifteenth-century Spanish poets, including Juan de Mena and Jorge Manrique. But it is the last and least concrete argument which is the weakest link in the chain, for it draws our attention to the enormous differences that exist between Terence and Celestina. Terence always, in his six surviving plays, uses five acts and writes in verse; he has a light touch, uses fast-moving and highly complicated plots (sometimes, indeed, practising contaminatio, i.e. combining two Greek comedies in his one Latin one), and in general avoids coarseness and obscenity; and though a young man's desire for a girl provides the motivation for his plots, love in Terence is a light diversion. Celestina consists first of sixteen and then of twenty-one acts, and is in prose; while its plot is extremely simple, the story moves slowly, the author probing the thoughts and motives of the characters; the humour is serious, and there is no shunning of the unpleasant aspects of life, whether brutal or obscene; and Celestina treats of love as a dominating, all-consuming passion and a moral sin. There is a huge gulf between the plays of Terence and Celestina.

I shall return to the question of verbal reminiscences; for the moment, let me just reemphasize that it is abundantly clear that the authors of Celestina did not imitate the form of the work from Roman comedy.

\section{Classical tragedy: Seneca.}

Another suggestion came from Leo Spitzer, who made it (1957) in reviewing Gilman 1956. Briefly, he seeks antecedents for Celestina in classical tragedy, rather than comedy, and, because of the heavy Stoic element in Celestina, the fusion of rhetoric and dramatic dialogue, most specifically in Seneca. ${ }^{4}$ There are, certainly, passages of the first act of Celestina which are literal translations from Seneca. The evidence is set out by Castro Guisasola (1924: 94-98), but, as he demonstrates:

a. All the borrowings come from Seneca's moralizing proseworks, not from his plays.

b. The most substantial passages quoted from Seneca all derive from the Epistulae morales (the letters to Lucilius) and are to be found in the first act of Celestina.

c. Other moral maxims from other works, such as De beneficiis and De vitiis, as well as from the Epistulae morales, are quoted by Rojas in Acts II-XXI, but could have reached him by a 
variety of routes, the most likely of which appears to be the Sententiae of Publilius Syrus, which, having lost the $\mathrm{N}$ to $\mathrm{V}$ section (they are alphabetically ordered) before the ninth century, was completed with the anonymous De moribus, falsely attributed to Seneca, and led a vigorous life, acquiring more maxims from a variety of sources, in the later Middle Ages [the complex situation is set out by Round 1972].

In short, there is no evidence that either of Celestina's authors knew the plays of Seneca, which are in any case formally as unlike Celestina as are the comedies of Terence. ${ }^{5}$

\section{Humanistic comedy.}

Other "dramatic" antecedents examined in connexion with the form of Celestina include the elegiac comedies of the twelfth and thirteenth centuries, but since there is no formal resemblance, and since elegiac comedy leads us on into some very complex questions, I postpone examination of the problem. ${ }^{6}$ There is really no possible doubt that the shape of Celestina owes everything to humanistic comedy.

Menéndez Pelayo argued (1962: 325) that there were only three humanistic comedies which could have influenced Celestina: Ugolino Pisani's Philogenia, Leonardo Bruni d'Arezzo's Poliscene (or Poliscena), and the Chrysis of Aeneas Sylvius Piccolomini. He then proceeded to eliminate Philogenia ("tengo muy por dudosa esta fuente," 326) and Chrysis ("puede tenerse por cierto que Rojas desconocía la existencia de la Chrysis," 330). Castro Guisasola disposed of humanistic comedy in two very brief paragraphs (1924: 145): "Para las analogías señaladas [by Menéndez Pelayo], remito al lector a los Orígenes de la novela [...]. Aquí sólo diré que ninguna de las semejanzas con nuestra Tragicomedia (como no sean las de la Poliscena) es concluyente." It would seem that Castro Guisasola, finding Menéndez Pelayo's parallels unconvincing and the texts difficult of access, did not think it worth while to investigate the matter on his own account. The unfortunate result is that in a book of almost 200 pages on the sources of Celestina, the most important source next to Petrarch is dismissed in nine lines.

The question was reopened in 1953 by José María Casas Homs's edition of a hitherto unknown humanistic comedy, the 
Poliodorus of Johannes de Vallata, but his remarks on "La Celestina y la comedia humanística" are tentative in the extreme, and it was left to María Rosa Lida de Malkiel, first reviewing Casas Homs in 1956, and then in her huge book of 1962, to put the case with the energy and decisiveness characteristic of her work.

Humanistic comedy, as distinct from other medieval drama in Latin, starts, like so much else, in fourteenth-century Italy, and its initiator was that remarkable innovator and greatest of European writers, Francesco Petrarca (Petrarch). It could be argued that the term "humanistic comedy" is something of a misnomer, since it might much more aptly be applied to the plays written by the humanists of the late fifteenth and sixteenth centuries, which are much closer imitations of classical comedy: humanism, indeed, in recovering purer classical standards, killed "humanistic comedy." Petrarch refers twice in his letters to his "comedia" Philologia, but his friend Giovanni Boccaccio writes that Petrarch "scripsit pulcherrimam comediam cui nomen imposuit Philostratus," and Francesco Nelli wrote to Petrarch in 1354 asking him to send copies of his plays: "Dic michi quando [...] legam [...] in commediis [tuis]" (Casas Homs 1953: 38-39). From a fragment of a letter described by Vittorio Rossi $(1945: 558, n .9)$ it would seem that the full title of one play was Philologia et Philostratus (like Calisto y Melibea), but whether Petrarch wrote more than one play remains obscure. At any rate no play of his survives, and we can gather very little about Philologia from the scattered references to it. In Boccaccio's view it was - like Act I in Rojas's view - superior to Terence; but it is also reported that Petrarch himself was ashamed of his play, having written it before becoming familiar with Terence (Lida de Malkiel 1962: 43, n.7). The only surviving fourteenth-century humanistic comedy is Pietro Paolo Vergerio's Paulus, but the fifteenth century saw an enormously increased production of these works. Those extant include Leonardo Bruni's Poliscene (of which there were numerous printed editions starting in 1478 , as well as a great many manuscripts), Leone Battista Alberti's Philodoxus (also frequently printed), Aeneas Sylvius Piccolomini's Chrysis (of which only one manuscript survives, though there are two modern editions), Ugolino Pisani de Parma's Philogenia (many times copied in manuscript and printed early) and his Confabulatio coquinaria, Vallata's Poliodorus, Canichiolus, Siccone Polentone's Catinia, Antonio Buzario or Barzicio's Cauteriaria, Columpnarium, the Comoedia bile, the Comoedia electoralis, the Comoedia sine nomine, Luigi Morelli's Dolos and another of the same title by Pietro de Roado, the Fraudiphilia of disputed authorship, 
Mercurius Rantius's Hypocrita, and Janus sacerdos; and we have secure references to the now lost Admiranda and Aphrodisia (see Casas Homs 1953: 249-52). ${ }^{8}$

On the whole, though one can put together a respectable specialist bibliography on humanistic comedy (see Lida de Malkiel 1962: 37-38, n. 6), little attention has been paid to these plays by scholars working on the vernacular literatures, and, as with so many other things, the ignoring of this Latin background has led to undue emphasis on the novelty of works in the vernacular and specifically, in this case, of Celestina.

It is not easy to summarize the characteristics of humanistic comedy, since one of its principal features is precisely the diversity of its formal aspects. Some works were clearly written to be read (Leonardo Bruni writes in the introduction to his Poliscene: "perlege tu [...] lector"), while others are known to have been performed, frequently by students. Some are short, mere interludes, and some are long. Some are in verse and some are in prose. The various authors employ a variety of styles, ranging from the pseudo-classical to the racy colloquial. All show a clear, even though superficial, debt to Roman comedy: in the names of the characters (they are all classical or pseudo-classical, even when they are not actually to be found in Terence), in the situations employed, in the vocabulary and odd lines quoted from Terence, and in such devices as the incorporation of stage-directions into the dialogue. But all this is in fact relatively unimportant, for these fourteenth- and fifteenth-century plays differ quite radically from Roman comedy, and in every major way in which they do diverge from classical drama they coincide with Celestina. The points of similarity between Celestina and humanistic comedy (excluding the few I have noted which they share with Roman comedy, such as the names of the characters) may be listed as follows:

a. The use of prose instead of verse (there are, of course, comedies in verse, but the very popular Philodoxus, among others, is in prose).

b. The flexible structure, which rarely accepts the restriction of the classical five-act symmetrical development. (Paulus has five acts, but Poliscene has thirteen scenes, Philodoxus has twenty, Chrysis has eighteen, Philogenia has fifteen, Poliodorus has twenty-six, and so on.) Sundry features of humanistic 
comedy are certainly related to this rejection of the more exigent form, but whether consequentially or causally it is not easy to say. Economy, for instance, is not a consideration (as it is in Roman comedy), so that situations are repeated, one finds unnecessary characters who do not advance the plot, and there are long digressions: their virtues rarely include conciseness. A further concomitant of the neglect of the classical structure is that these works are often rather shapeless, and it could be argued that (as with many another medieval work - see Spearing 1964: 24-25 and 46-67) the units of construction, in this case the scenes, show pattern and organization which is not evident in the work as a whole. Some humanistic comedies are indeed little more than a succession of semi-independent cuadros, linked by a very slender plot: which is to say that there is little unity of action.

c. The treatment of space and time, which is quite unlike that in Roman comedy. In humanistic comedy, as in Celestina, the action takes place in numerous different settings; there are monologues and dialogues which take place as the characters move from one part of the town to another; conversations start outdoors and finish indoors, and so on. This may be explained partly by the authors' writing for readers rather than actors, partly, in the plays which were acted, by the absence of stage properties and machinery. But it is also parallelled by (and there may be some link with) an equally flexible concept of time, so that we can have the successive representation of scenes which are actually simultaneous, or the elapse of time between scenes or acts. Again, the classical unities are ignored.

d. Greater realism and lack of decorum. Though there is no doubt much in humanistic comedy which could be argued to be realistically unlikely, the verisimilitude of the genre is incomparably greater than in the plots of Plautus and Terence, which rely on far-fetched coincidences, mistaken identities (notably with identical twins), and so forth. The background in humanistic comedy tends to be sketched in very much more fully, so that from some we can gather numerous realistic details of life in contemporary Italy. (Similar vivid little touches in Celestina have been much praised.) Though some Roman comedy might be adjudged mildly indelicate, some humanistic comedy is quite scabrous, examining incest, homosexuality, and the like. There is, of 
course, no reason to suppose that the bawdy and crudity of certain scenes of Celestina necessarily derive from Italian humanistic comedy, since both are in this respect typically medieval.

e. The characters. Humanistic comedy does make use of the stock types of Roman drama. The standard characters in these plays are: a pair of lovers, their servants, and a gobetween, with the less consistent appearance of parents, prostitutes, and other characters. But there is also in humanistic comedy a variety of types not to be found in Roman comedy, such as the deceived husband, the amorous priest, and the old woman in love, and the stock characters themselves are not fixed types, so that one finds variation within the accepted categories. Perhaps the most radical innovation is in the heroine, who is typically (like Melibea) passionate, independent, and given to protesting against the social conventions which restrict her freedom.

In Roman comedy in general the characters behave in such a manner as to secure certain obvious objectives (usually a woman or wealth), which are clearly felt by the author to require no justification, and the characters' emotions (fear, guilt, remorse, affection, love, loyalty, etc.) are facts given to explain their conduct but emotions which neither Plautus nor Terence feels impelled to analyse further, justify, or explain. But in humanistic comedy the motivation of the characters is examined in much greater detail, and one frequently finds meandering introspection, indecision, and internal conflict.

In harmony with the realism and lack of decorum I have mentioned, one finds little high-flown sentiment in humanistic comedy. The lovers are motivated by lust and their servants by self-interest, and parents are more frequently actuated by greed than by affection or thoughts of honour. In general the atmosphere is much more like that of the Decameron than that of Terence.

f. The mixture of styles: there is in most humanistic comedies a non-classical mingling of stylistic levels.

One could argue that humanistic comedy represents an attempt at emulating the classical writers of comedy by Italians conditioned by medieval literary theory and practice -that is, to put it crudely, a cross between Roman comedy and medieval drama. One might, therefore, go on to enquire whether the author of the first act 
of Celestina might not have arrived at a similar form by a similar route, and whether, given Act I as a model, Rojas need have been familiar with the humanistic comedy of Italy. But the general resemblance of form and treatment - which are such that the only proper label for Celestina is "humanistic comedy" - are also accompanied by a number of other coincident features, such as the use of a prefatory letter. It is true that some coincidences may be due to chance, to common sources, or to European traditions, but it is impossible that all the features common to Celestina and Italian humanistic comedy could have arisen independently. In his prose Philodoxus, written in 1426, Leone Battista Alberti says in a prefatory letter (addressed to Leonello d'Este) that he wrote it in fifteen days while a law student at Pavia. In Ugolino Pisani's Philogenia there is a character called Calixtus (the heroine's father), and a scene (like that in Act XII of Celestina) in which the parents are disturbed by a noise in their daughter's room. In Leonardo Bruni's Poliscene the gobetween, Tharatantara, has a reputation as a witch; there is a passage in which she recalls the joys of youth which is strongly reminiscent of Celestina's discourse on the topic; and exchanges between the gobetween and Poliscene could have suggested those between Celestina and Melibea. The Paulus of Pietro Paolo Vergerio is subtitled "ad iuvenum coercendos mores." Sundry writers refer to the controversy their work has excited. And so on. Lida de Malkiel (1956) has listed an even greater number of similarities. Both the original author of Act I and Fernando de Rojas must have known some humanistic comedy.

Menéndez Pelayo found the problem of transmission difficult, inasmuch as the earliest authenticated representation of a humanistic comedy in Spain did not take place until the sixteenth century (at Salamanca), and the texts were printed late in Spain (the earliest Spanish edition of Philodoxus, for instance, is Salamanca 1501). But these difficulties seem to me quite unreal. In the first place, we do not have to suppose that either of Celestina's authors need have watched a performance of a humanistic comedy, and the fact that these works were printed late in Spain signifies nothing: the Petrarch which Rojas indubitably used was printed in Basel, and humanist texts found their way to Spain readily enough from printing centres all over Europe. Menéndez Pelayo's point that manuscripts of these works are lacking in Spain is also wholly inconclusive on at least two counts: one, that it is not true, and two, that even it were true it would not mean that printed editions were not available. 
A more real difficulty is encountered when one tries to guess at which of this large number of humanistic comedies the authors of Celestina might actually have read. The only suggestion I have to make is that perhaps the likeliest source is the Margarita poetica.

\section{The Margarita poetica.}

Albrecht von Eyb (Albertus de Eyb, Eib, Eiib, Eijb), [1420-75], was one of the earliest of the German humanists, who published, among other things, a summary of Book 2 of Petrarch's De remediis utriusque Fortunae, one of the earliest editions of two comedies of Plautus (the Menaechmi and the Bacchides: he printed them with Ugolino Pisani's Philogenia in 1518), a German translation by himself of the Philogenia, and the enormously popular Margarita poetica.

The most cursory investigation, looking no further than the catalogues of the British Library, the Bibliothèque Nationale in Paris, and the Biblioteca Nacional, shows that there were at least a dozen editions of this work which Rojas could have known. The first edition was printed in Nuremberg by Johann Sensenschmid in 1472 (BL and BNP), and thereafter there are editions by G. Husner, Strasbourg 1473? (BL); by U. Gallus, alias Han, Rome 1475 (BL and BNP); an incomplete edition of Paris c. 1475, noted by bibliographers but apparently not in BL, BNM, or BNP; by Simonel, Blandin, and Simon, Paris 1477 (BNP); by Ulricus Guering, Paris 1478 (BL and BNP); by Stephanus Plannck, Rome 1480 (BL and BNP); of 1487, without place but Venice (BL); by J. Rubrus, Venice, without date but 1493 ? (BNP); of 1493, without place but Venice? (BL); and by Johann Amerbach, Basel 1495 (BL, BNM, and BNP). In addition, as well as the sixteenth-century editions which are too late for Rojas to have known before writing Celestina, there are an undated Nuremberg edition by Sensenschmid and Kefer (BNP), two quarto editions without imprint (BNM), and one folio edition without imprint (BNP), all of which could be presumed to be incunables. According to Casas Homs (1953: 54, n. 13) there are two copies of the Margarita in the Biblioteca Universitaria of Barcelona, but he does not say what editions they represent. There are copies of some of these editions in Oxford, Cambridge, Edinburgh, and doubtless many another library. This makes the Margarita a best-seller among early printed books.

The work itself is a compendium of quotations from the poets, historians, and philosophers, but also an ars poetica and manual of 
letter-writing ("de arte dictandi ac practicandi epistolarum opus") and an anthology of model passages selected from, among others, Plautus and Terence, and the humanistic comedies Philodoxus, the grossly scabrous Comoedia de falso Hypocrita et tristi of Mercurius Rantius (or Roncius) Vercellensis (performed in Pavia in 1437), and the Philogenia of Ugolino Pisani (including the soliloquy of the love-lorn hero Epifebus).

No one has as yet carefully examined the Margarita to see how much it might have contributed to Celestina. ${ }^{10}$ But if there are difficulties in supposing that Rojas could have known Aeneas Sylvius's Chrysis, which the author did all he could to suppress after he became Pope Pius II, there is no difficulty in supposing that Rojas could have known Leonardo Bruni d'Arezzo's Poliscene nor, via Albrecht von Eyb, fragments of Philodoxus and Philogenia, and odd lines and extracts from Plautus and Terence.

\section{Conclusions}

We are now in a position to return to the alleged influence of Terence on Celestina. Castro Guisasola takes nine pages (1924: 82-90) to list the "borrowings" from Terence, and even insists (86) that he would never be done if he tried to list them all. But they are a miscellaneous collection, and of the twenty-six alleged reminiscences, the least sceptical reader would surely be doubtful about many. Some are completely trivial (like "Ha, ha, hae!" "Quid risisti?" / "¡He, he, he!" "¿De qué te ríes?"), and most of the remainder are only vaguely similar. Wherever one does find a clear and unequivocal borrowing, involving one of Rojas's typical word-for-word translations (like "Amantium irae, amoris reintegratio est," rendered by Sempronio as "Las yras de los amigos siempre suelen ser reintegración del amor," Cejador 1913: II, 16), it turns out to be a secondary borrowing (in this instance from Petrarch's Epistulae familiares, V.8). In fact the only undeniable cases are those taken at second hand from Petrarch. This makes the literal non-comparability of the remaining "borrowings" highly suspect.

There are, nevertheless, two curious features about Castro Guisasola's "situaciones análogas" (as he ends by calling what at the beginning he said were textual reminiscences): one is that there are rather too many of these vaguely similar parallels for us to dismiss them without some misgiving, and the other is that they are for the 
most part restricted to just two Terentian comedies, Andria and Eunuchus. The fact that Rojas does not take anything directly from Terence word for word could be explained by his not possessing a copy of these plays when he wrote Celestina. But whether he had at some earlier stage read Andria and Eunuchus we may perhaps never settle satisfactorily. They could have reached him via humanistic comedy. Castro Guisasola reverses this argument by saying (1924: 90, n. 1) that while these "analogues" are also to be found in humanistic comedy, it is the influence of Terence on both Rojas and humanistic comedy that explains the similarities between the latter and Celestina. This, however, is clearly wrong: Terence is not the "modelo inmediato de Rojas," and the form of Celestina is that of a humanistic comedy; but whether Rojas got his Terence from Terence, from humanistic comedy, or from a work like the Margarita poetica is something that only further research can clarify. Someone, in fact, has still to do the job which Castro Guisasola, who had the right gift for it, most unfortunately decided would be unprofitable.

I have dealt with this problem at some length, since it seems to me a typical and all-too-familiar case in hispanist criticism. Scholars find "sources" for medieval works in what are now wellknown classical texts while ignoring all the then best-known writers in Latin (Boethius, Peter Comestor, Peter Lombard, St. Bernard, Thomas Aquinas; Jacob a Voragine, and others) along with the allimportant and very numerous compendia and the teaching and preaching manuals in which all manner of anecdotes, descriptions, images, fragments of verse, and sententiae were anthologized and preserved as models. The older critics were convinced that Celestina was modelled on Terence; Lida de Malkiel (1962) has demonstrated unequivocally that it is in innumerable ways a typical humanistic comedy; but even she barely mentions (there are only three passing references) the Margarita poetica, which was actually the most widely diffused text of all.

To sum up the situation so far: the only sure sources from earlier drama which we are obliged to posit for the authors of Celestina are some compendium, almost certainly a late medieval version of the Sententiae of Publilius Syrus, to account for the fragments of Seneca

(the author of Act I had also read the letters to Lucilius), and one sample of a humanistic comedy (possibly the readily accessible Poliscene) and/or the Margarita poetica. 


\section{BIBLIOGRAPHY}

Casas Homs, José María, ed., 1953. Johannes de Vallata, "Poliodorus": comedia humanistica desconocida. Madrid: CSIC.

Castro Guisasola, F., 1924. Observaciones sobre las fuentes literarias de "La Celestina," Anejos de la RFE, 5. Madrid: Centro de Estudios Históricos.

Cejador y Frauca, Julio, ed., 1913. Fernando de Rojas, La Celestina, Clásicos Castellanos, 20 \& 23. Madrid: La Lectura.

Corfis, Ivy A., 1984. "Fernando de Rojas and Albrecht von Eyb's Margarita poetica," Neophilologus, 68: 206-13.

Deyermond, Alan, in press. "Keith Whinnom's Celestina Book," in Medieval Hispanic Studies in Honor of Charles F. Fraker (Madison: HSMS).

Fothergill-Payne, Louise, 1988. Seneca and "Celestina." Cambridge: UP.

Fraker, Charles F., 1990. "Celestina": Genre and Rhetoric. London: Tamesis.

Gilman, Stephen, 1956. The Art of "La Celestina." Madison: Univ. of Wisconsin Press.

----, 1962. "Rebirth of a Classic: Celestina," in Varieties of Literary Expression, ed. Stanley Burnshaw (New York: New York UP), 283-305. (Revised in Spanish as "Introducción" to Severin 1969: 7-29.)

----, 1972. The Spain of Fernando de Rojas: The Intellectual and Social Landscape of "La Celestina." Princeton: UP.

Herrmann, Max, 1893. Albrecht von Eyb und die Frühzeit des deutschen Humanismus. Berlin: Weidmannsche Buchhandlung.

Hiller, Joseph Anthony, 1939. Albrecht von Eyb, Medieval Moralist. Washington: Catholic Univ. of America.

Lacarra, María Eugenia, 1990. Cómo leer "La Celestina," Guías de Lectura Júcar, 5. Madrid: Júcar.

Lawrance, Jeremy, 1993. "On the Title Tragicomedia de Calisto $y$ Melibea," in Letters and Society in Fifteenth-Century Spain: Studies Presented to P.E. Russell on his Eightieth Birthday (Llangranog: Dolphin), 79-92.

Lida de Malkiel, María Rosa, 1956. Review of Casas Homs 1953, NRFH, 10: 415-39.

----, 1962. La originalidad artística de "La Celestina." Buenos Aires: Eudeba.

Menéndez Pelayo, Marcelino, 1962. Orígenes de la novela, III [1910], Edición Nacional de las Obras Completas. Santander: CSIC. 
Rossi, Vittorio, 1945. Storia letteraria d'Italia: il Quattrocento, 3rd ed. Milano: Francesco Vallardi.

Round, Nicholas G., 1972. "The Mediaeval Reputation of the Proverbia Senecae: A Partial Survey Based on Recorded MSS," Proceedings of the Royal Irish Academy, Section C, 72: 103-51.

----, 1974-79. "Las traducciones medievales catalanas y castellanas de las tragedias de Séneca," Anuario de Estudios Medievales, 9: 187227.

Russell, Peter E., ed., 1991. Fernando de Rojas, Comedia o Tragicomedia de Calisto y Melibea, Clásicos Castalia, 191. Madrid: Castalia.

Severin, Dorothy S., ed., 1969. Fernando de Rojas, La Celestina: Tragicomedia de Calisto y Melibea. Madrid: Alianza.

Spearing, A.C., 1964. Criticism and Medieval Poetry. London: Edward Arnold.

Spitzer, Leo, 1957. "A New Book on the Art of La Celestina," HR, 25: 1-25.

Stäuble, Antonio, 1968. La commedia umanistica del Quattrocento. Firenze: Istituto Nazionale di Studi sul Rinascimento.

Webber, Edwin J., 1956. "The Literary Reputation of Terence and Plautus in Medieval and Pre-Renaissance Spain," $H R, 24: 191-$ 206.

----, 1957-58. "Manuscripts and Early Printed Editions of Terence and Plautus in Spain," $R P h, 11: 29-39$.

Whinnom, Keith, 1989. "Albrecht von Eyb's Margarita poetica: What Every Celestinista Should Know," ed. Alan Deyermond, Celestinesca, 13.2 (Nov.): 45-47.

Wolf, Ferdinand, 1859. Studien zur Geschichte der spanischen und portugiesischen Nationalliteratur. Berlin: A. Asher. 


\section{NOTES}

1. [In addition to Webber 1956 and 1957-58, see now Fraker 1990: chap.2, and Russell 1991: 37-45.]

2. [This question and some others treated in the present article are discussed by Lawrance 1993.]

3. [All quotations are from Cejador's Clásicos Castellanos edition, first published in 1913, which had reached its 9 th impression - whimsically described by the publishers as 9 th edition - by the time Whinnom was writing. I do not know to which impression(s) his working copy belonged, but the page-numbers pencilled on the typed draft correspond to those in my own copy, in which vol. I is of the 3rd impression and II of the 4th (1945. and 1949 respectively).]

4. [For knowledge of Seneca's tragedies in medieval Spain, see Round 1974-79. Louise Fothergill-Payne renews the case for some influence of Seneca's tragedies on Celestina, 1988: 128-35.]

5. [In Whinnom's typed draft of this chapter, the section on Seneca is followed by the first fourteen lines of a section 3 on elegiac comedy, Pamphilus de amore, and the Libro de buen amor, which he describes as "a vexed and complex question." These lines, which end in mid-sentence, are crossed out, and the page is followed by a new section 3.]

6. [Whinnom says he postpones it "until the next section," i.e. the next chapter, but if this was ever written, apart from the lines mentioned in note 4 , above, it has not survived.]

7. [The standard treatment of the genre is by Stäuble 1968. For its relation to Celestina, see now Russell 1991: 45-52.]

8. Lida de Malkiel (1962: 37-38, n. 6) drafts a slightly different catalogue, excluding a few items - those, apparently, which she was unable to see - and adding to Casas Homs's list seven plays by Tito Livio Frulovisi and the anonymous Aetheria.

9. For further information on this very important and neglected figure one can consult Hiller 1939; pp. 69-111 are on the Margarita poetica. [See also Herrmann 1893; pp. 174-214 on the Margarita. Whinnom decided in 1985 to give an account of the work for Celestina specialists, but his final illness prevented him from doing more than writing the first couple of pages; I have edited the fragment in this journal: Whinnom 1989.] 